\title{
Subjectivity and Ideological Interpellation: An Althusserian Reading of Bozorg Alavi's Her Eyes
}

\author{
${\text { Baktiar Sadjadi }{ }^{1 *} \text {, Alireza Ahmadirad }}^{2}$ \\ ${ }^{1}$ Faculty of Foreign Languages, University of Kurdistan, Sanandaj 66177-15175, Iran \\ ${ }^{2}$ Islamic Azad University at Tehran Central, Tehran, Iran
}

Corresponding Author: Baktiar Sadjadi, E-mail: b.sajadi@uok.ac.ir

\section{ARTICLE INFO}

\section{Article history}

Received: September 18, 2017

Accepted: November 10, 2017

Published: January 05, 2018

Volume: 7 Issue: 1

Advance access: December 2017

Conflicts of interest: None

Funding: None

\begin{abstract}
The present study seeks to critically investigate Bozorg Alavi's celebrated Persian novel, Čašmhāyaš (Her Eyes), in terms of Louis Althusser's concepts of ideology, interpellation and, most significantly, the subject/Subject model. Althusser developed the notion of 'interpellation,' that is the procedure through which individuals become subjects by what he called Ideological State Apparatuses. Accordingly, there exist 'subjects' and 'the Subject' at work precisely in the way 'ideologies' and 'Ideology' are present in the process of subjectivization. The subject is the individual who turns into being interpellated whereas the Subject is required by ideology. Bozorg Alavi's Her Eyes, considered as chef-d'oeuvre in the realm of modern Persian realist fiction, portrays a protagonist who is wholeheartedly attached to his ideological Cause, a character who dedicated his whole life to socialist ideals. Alavi's masterful depiction of the protagonist, Master Makan, and other major characters including Farangis in particular, demonstrates the way individuals are both consciously and unconsciously recruited by ideology, a process through which the subjects attempt to impersonate the Subject. Structurally, the ideological devotion in the protagonist, here to the communist Tudeh Party, entangles the subjects with a closed domain in a destructive manner that leads to their downfall.
\end{abstract}

Key words: Ideological State Apparatuses, Interpellation, The Subject/Subject Model, Ideology, Persian Novel, Tudeh Party

\section{INTRODUCTION}

Bozorg Alavi (1904-97) was born in Tehran to a family deeply engaged in the constitutionalist movement of the early twentieth century. He was one of the pioneering figures in modern Persian literature who tried his hand at writing novels, novellas, and political tracts contrary to conventional literary forms of the era. In 1932, he happened to meet Sadeq Hedayat, a leading figure in modern Persian literature, with whom and two other figures, Masoud Farzad and Modjtaba Minovi, they founded a coterie with modernist tendencies entitled Rab'a, which signifies a group of 'four' writers. Alavi's first published book, Čamadān (The Suitcase) (1935), was a collection of six stories written under "Freud and Hedayat's influence" (Abedini 197). Alavi was jailed by Pahlavi Regime from 1937 to 1941, an agonizing era during which he wrote his distinguished work recounting his agonies in prison, Varaq-pārahâ-ye Zendan translated by Donne Raffat as The Prison Papers of Bozorg Alavi: A Literary Odyssey (1985). After his release from prison, Alavi was recruited by Toudeh Party, a party totally directed by communist tendencies, in which Alavi played a leading role, particularly in formulating the Party's cultural policy. Alavi was exiled to Germany twice in his life span, once after 1953 coup against Premier Mohammad Mossadegh, and later after the 1979 Revolution. Alavi's literary landmark, Čašmhāyaš (Her Eyes) was published in Iran in 1952 which was almost immediately banned from the public audience.

Alavi belonged to the realistic tradition of Persian writers whose outstanding feature of realism is "a sort of moderation that distinguished him from his contemporaries" (Baghinezhad and Alizadeh 62). More precisely, as Abedini argues, Persian realistic tradition tends to emancipate itself from the tangles twisted with raw symbolism and vulgar orthodoxy (229). With the advent of the above mentioned new movement, Alavi attempted to set "social realities as the basis of his novels" (ibid). Alavi's realism, a juxtaposition of love, politics, and political reforms, tends to create an emotional and political climate; consequently, to reach this end, Alavi took advantage of the established "twists in detective stories" (Abedini 18). The implementation of the detective method culminates in the readers' fascination with the conundrums and contradictions embedded throughout the story. The recurrent dialogues and recounted memories which usually lead to the final resolution are among Alavi's key literary devices.

Notwithstanding that all of Alavi's works were warmly received by both the critics and the public, Her Eyes has been unanimously regarded as his magnum opus. According 
to IBNA, Iranian Book News Agency, Her Eyes has so far undergone more than a score of editions by different publishing centers. The novel enjoys a wide audience not only because of its interesting subject, which is a game between love and politics, but, particularly, in that its style and language are common, fluent, and easily-read. The descriptions of the characters and setting are minute, clear and lifelike. Her Eyes is a classic example of Persian realist tradition and, consequently, lacks the complicated modernist techniques of narration, namely stream of consciousness and neologism. Correspondingly, it is one of most popular novels among common Persian readers.

On the other hand, closely in association with Marxist literary theory and criticism, Louis Althusser had a significant role in the revival and development of socialist theory in the 1960s. Seeking to reunite Marxism and Structuralism, he managed to present a highly distinguishable definition of ideology and the subject. His concepts of ideological interpellation, the Ideological State Apparatuses, Repressive State Apparatuses, and particularly, the subject/Subject model have ever since had a crucial function in Marxist analysis of literary and cultural texts.

This study endeavors to critically analyze the ways in which individuals are transformed into subjects through a process Althusser called ideological interpellation. As far as ideologies make use of diverse apparatuses to recruit subjects, the processes in which individuals are hailed, in the Althusserian sense, as well as the manner subjects attempt to tread in the Subject's steps, are to be investigated in terms of the Althusserian model of the subject/Subject. Although Althusser is a well-known figure in contemporary critical discourse, particularly for his challenge in redefining ideology and mostly for introducing the concept of interpellation, his model of the subject/Subject has been usually neglected in the critical reading of different texts.

In the present paper the plot summary of the novel is first introduced and the following section addresses the methodology, objectives, and the approach. Then, a detailed study of the critical concepts employed in the present research is introduced. The literature review section follows next. It includes a close review of the previous studies of the novel under consideration. Afterwards, the key section of the paper is presented which provides a detailed reading of Her Eyes in terms of the Althusserian notion of ideological interpellation and particularly, his model of the subject/Subject.

\section{PLOT SUMMARY}

Her Eyes, a novel based on a story replete with passionate love and political aspirations, is crafted by a "fluid and rhythmic prose" (Sepanlou 155) captivating the reader to the very end of the story. The political atmosphere of the 1940s in Iran and, particularly, the conflict between the central government and the socialist movement of the day provides the context in which the events of the novel are set. The novel revolves around the belated love of a stunning aristocrat girl, named Farangis, towards a renowned painter, Master Makan, who undergoes devotion to his political and ideological Cause. The title of the novel is borrowed from Master
Makan's most recent painting entitled "Her Eyes," whose mystery will be resolved by a schoolmaster who dedicated himself to uncovering the holder of the eyes. The schoolmaster's primary aim is to resolve the enigma of Master Makan's private life; hence, he keeps waiting for years to meet the woman who holds the eyes. It is in the second chapter of the story that he captures the sight of the awaited woman with whom he sets an appointment in her mansion to give ear to the real story.

In the course of the story, it is revealed that Farangis, on her visit to Master's gallery, exits the gallery with frustration and discouragement due to Master's cold conduct towards her paintings. She leaves Iran to France in order to academically work on art studies; however, she keeps a sentiment in her bosom for Master Makan. On her return to Iran, she meets Master Makan again and falls deeply in love with him. Master Makan is quite hesitant to return her love since he feels utterly devoted to his political and ideological Cause.

Later on, Master Makan is jailed by Reza Shah's repressive police and exiled to a remote town. Meanwhile, Farangis surmises that the mere solution to save Master Makan's life is to marry Sarhang Aram, the head of intelligence service, with whom, ultimately, Farangis is wedded. This matrimony, contrary to Farangis's mentalities, turns into an enigma both to Farangis and the reader; it is unfathomable whether Farangis's sacrifice, her marriage to Sarhang Aram, was ever perceived by Master Makan. Despite the fact that it appears Master Makan is on the brink of succumbing to his attachment to Farangis, he constantly resists the temptation since he deems it as a disloyalty to the Cause.

\section{METHODOLOGY: OBJECTIVES AND THE APPROACH}

Considering the Althusserian subject/Subject as a major critical model in the analysis of the identity construction, the present paper contends that its exploration provides a highly comprehensive account of the process of ideological interpellation and the subject formation. The paper thus considers this model as a critical perspective for the analysis of the representation of subjectivity in fiction. This approach is, first of all, applicable to various phases in the development of identity construction of the subject including both the infantile and mature years. Furthermore, it investigates the subject from an extensively significant aspect that is its relation to ideology; likewise, it brings into consideration the relation of the subject to both the individual and the social and, accordingly, focuses on the Ideological State Apparatuses as the realm where they meet.

The objectives of the present research are twofold: first, it aims to focus on the angles the represented subjects in the novel are positioned between distinguishable ideological contexts; secondly, it demonstrates through which perspectives the application of the subject/Subject model to reviewing a literary work is illuminating in a better understanding of the construction and representation of the subject's identity. Therefore, the goal of the present research could be categorized as an exploratory study that structures and identifies new problems in the area of literary criticism. 
The present study compatibly provides an elaborate analysis which consists of the selection and discussion of theoretical and descriptive material as well as a detailed comparison of theories in terms of their applicability. The research method of the existing paper is thus qualitative and categorized as theoretical study; correspondingly, the current survey will be entirely literature-based in that, in the academic library research, the conclusions are built on the analysis of the data referring to a particular area. Being a case study, the existent research includes a close and in-depth examination of a single event in contemporary literary and critical approach, namely the subject/Subject model in the Althusserian theory.

\section{CRITICAL CONCEPTS}

The commencement of Althusser's work coincided with the radical novel methodology applied to the social sciences known as structuralism which, in turn, was the offspring of Saussure's structural linguistics. By the mid-1960s, structuralism was the most-favored methodology amongst French intellectuals. Althusser took advantage of structuralism that provided him with some specific approaches to the interpretation of Marx's works and these pros assisted Althusser in two ways. At the first step, structuralism was anti-humanist in the sense that it rejected the role of conscious decisions of individuals in forming cultural phenomena; on the other hand, these phenomena were taken into accounts as the products of abstract social contracts among the members of society.

The significance of Althusser's work lays in its mapping out a Marxist theory of ideology which disregards any economic determinism to the advantage of the relative autonomy of ideology. The Althusserian notion of the constitution of society and his spectacular terminology including "relative autonomy of social practices, "over-determination," "the complex whole," and "the structure in dominance" have been ever since of extensive interest to critics. The point that has made his ideas considerably distinguishable from his contemporary leftist critics' is that Althusser paid little credence to consciousness, subjectivity, and identity outside the domain of ideology. He conceived of ideology as systems of representation with practical and theoretical aspects, granting priority to the practical side; in other words, ideology is a set of discourses, images, and opinions surrounding the condition of our lives.

Althusser sought to explore the mutual relationship between the subject and ideology in his essay "Ideology and Ideological State Apparatuses" in Lenin and Philosophy and Other Essays (1970). Addressing dissimilar approaches and modes of the process of subjecthood, he developed the notion of interpellation which is the procedure through which individuals develop into subjects. Althusser wrote, "All ideology hails or interpellates concrete individuals as concrete subjects, by the functioning of the category of the subject" (173).When the individuals are exposed to ideology and act according to its rules, they are altered to the subjects of that ideology. Interpellation occurs the time the subjects are hailed directly or dramatically by ideology.

In order to maintain the relations of production, individuals have to be able to supply the social demand; subsequently, this goal could be achieved by creating social concrete subjects through the process of ideological interpellation. In his essay "Ideology and Ideological State Apparatuses," Althusser defines the meaning and function of interpellation as the following:

I shall then suggest that ideology 'acts' or 'functions' in such a way that it 'recruits' subjects transforms them all by that very precise operation which I have called interpellation or hailing. (174).

He brings an instance for interpellation in everyday life: a theoretical scene takes place on a street and a police hailing 'Hey, you there!' The hailed individual turns around to respond to this hailing being trapped as a subject recognizing himself to be addressed by that hail. Experiences demonstrate that hailings are precise and hardly ever missed, since the hailed individual eternally distinguishes himself as the hailed subject. It thus appears obvious that interpellation is an ideological hailing. The capitalist societies make use of this process of interpellation for maintaining and reinforcing their authority and domination over the public without using strength and power.

Althusser states that an ambiguity arises from the term subject: (1) a free subjectivity, a centre of initiatives, author of and responsible for its actions; (2) a subjected being, who submits to a higher authority, and is therefore stripped of all freedom except that of freely accepting his submission (182). The vagueness is in that the first implication is about a free subject who acts according to his will, correspondingly responsible for his own actions. On the other hand, the second sense represents a restrained subject whose acts are unerringly according to the authority which overpowers him and the single act that he performs freely is subordinating to the rules. Ideology, thus, gives counterfeit and false identity to these subjects. Accordingly, individuals suppose themselves as liberated agents and human beings. In reality, out of their freedom, these subjects succumb and work all by themselves as they are free human beings who act according to the rules of ideology's system and through that they recognize themselves and accept their subjection. In Althusser's words:

The individual is interpellated as a (free) subject in order that he shall submit freely to the commandments of the Subject, i.e. in order that he shall (freely) accept his subjection, i.e. in order that he shall make the gestures and actions of his subjection 'all by himself'. There are no subjects except by and for their subjection. That is why they 'work all by themselves.' (Lenin and Philosophy 182).

The process of interpellation is an ideological act and it possesses a structure which is common in all ideologies. It is the interpellation of individuals as subjects that is conducted by a Unique and Absolute Subject; it could be taken as a mirror-structure. This mirror structure consists of ideology and its function; in other words, ideology is located in the center, the place that the Absolute Subject resides. It interpellates to the eternity of this process: the surrogation of individuals into subjects and the subjection of subjects to the Subject. Each subject could be considered its own image (present and future) in the Subject. Althusser, in consequence, sum- 
marizes the "duplicate mirror-structure of ideology" in the following way:

1. The interpellation of 'individuals' as subjects;

2. Their subjection to the Subject;

3. The mutual recognition of the subjects and Subject, the subjects' recognition of each other, and finally the subject's recognition of himself;

4. The absolute guarantee that everything really is so, and that on condition that the subjects recognize what they are and behave accordingly, everything will be all right: Amen - 'So be it' (ibid 180).

Althusser investigates the subjection of the subject to the prevailing ruling class and ideologies at the same time. These subjects acknowledge their subjugation under the capitalist societies. They recognize their destiny as a natural one and assume that it is as it should be; ergo they are remodeled as a part of the system which is arranged by the higher authority. Two groups of subjects are traceable; good and bad ones. Althusser indicates that bad subjects are destined to exclude from the process of interpellation. He states:

Caught in this quadruple system of interpellation as subjects, of subjection to the Subject, of universal recognition and of absolute guarantee, the subjects 'work', they 'work by themselves' in the vast majority of cases, with the exception of the 'bad subjects' who on occasion provoke the intervention of one of the detachments of the (repressive) State apparatus. But the vast majority of (good) subjects work all right 'all by themselves', i.e. by ideology (whose concrete forms are realized in the Ideological State Apparatuses). They are inserted into practices governed by the rituals of the I SAs. They 'recognize' the existing state of affairs (das Bestehentie), that 'it really is true that it is so and not otherwise', and that they must be obedient to God, to their conscience, to the priest, to de Gaulle, to the boss, to the engineer, that thou shalt love thy neighbour as thyself', etc. (181).

Individuals unconsciously act according to the ruling social class and the prevailed ideology. They participate in the process of interpellation or hailing by obtaining the dominant ideology and acting according to the rules of the authority system which overpowers them. Interpellating or hailing to the upper power switches them from individuals to subjects. As Althusser stated "the existence of ideology and the hailing or interpellation of individuals as subjects are one and the same thing" (175).

Accordingly, the main doctrine in the Althusserian theory of subjectivity is that "ideology interpellates individuals as subjects." It is through interpellation that the subjects are constituted as the effects of pre-given structures. This process demonstrates the procedure that the subject recognizes his/her relation to reality and it is also a confirmation of the subject's ideological position:

I shall then suggest that ideology 'acts' or 'functions' in such a way that it 'recruits' subjects among the individuals (it recruits them all), or 'transforms' the individuals into subjects (it transforms them all) by that very precise operation which I have called interpellation or hailing, and which can be imagined along the lines of the most commonplace everyday police (or other) hailing: 'Hey, you there! (183)

This 'hailing' could be interpreted as a call for participation in the practice of an ideology; thereupon, successful hailing occurs if the subject recognizes that the hail is in actuality addressed to him/her. If a hailing is triumphant, the individual is metamorphosed into a subject of that particular ideology. When the hailed individual in the street turns round owing to the hailing of police, "he becomes a subject." $\mathrm{He} /$ she turns round on the grounds that he/she has recognized that "the hail was 'really' addressed" to him/her.

The subject is unconsciously and involuntarily directed by ideology to get closer to the Subject; however, the subject is never augmented to be the Subject. It is a fact that ideology has always covered; it is an undisclosed fact in a mechanism behind the function of ideology. The subject and the Subject are both continuously at work in a sense that the Subject is what the subject seeks to reach. The Subject is, on that account, the ideal subject defined by ideology, one that is never met by the subject. In other words, the subject never experiences the state of being a Subject.

\section{REVIEW OF LITERATURE}

Her Eyes has received diverse literary and even political critiques by critics both inside Iran and abroad. A great number of these writings address the literary devices of the novel as well as the historical and ideological contexts in which the novel was written and set. However, the number of the criticisms involved in the formal and structural aspects of the novel is relatively low.

According to Sadeqi and Bizhani in their study on the temporal structure and time levels of Her Eyes, the novel structurally consists of "five loops" (55). This five-loop structure of the novel grants the writer to pass the borders of linearity and come up with a non-linear structure. Recurrent shifts in the course of narration between past and present grant the reader the opportunity to feel captivated by the vibrations of the novel. Sadeqi and Bizhani have predominantly focused on the non-linearity of the story; they argue that there are at least three different time levels that provide the story with a non-linear feature and, accordingly, the story is not narrated in a chronological order.

Speaking structurally, one might argue that most realistic literature is based upon causal relationships to make the story justifiable. Following Todorov's thesis in his paper "structural analysis of narrative," Sadeqi and Bizhani contend all narrative follow a three part structure. However, they believe that although the story is apparently complex, it embodies a coherent structure and is considered as a multi-layered narrative. They contend "this causality infused with the structure of the novel is not to come up with a linear story but to expose the inherent tension within the texture of story and traits of its characters" (57). In effect, Her Eyes commences with a complication; Master Makan's death and, then, the indirect exposition of the "social facts prior to Master Makan's death" serve to resolve the complications (ibid). Accordingly, at the end of the novel the reader is assumed to conjecture that the recounted social, 
political, and personal accounts could have resulted in Master Makan's death.

In a review written on the novel, Haleh Esfandiari draws an analogy between Master Makan and a prominent contemporary Persian painter. In actuality, Esfandiari deems the issue as the impetus of the controversy sparkled by the novel on its release and argues that "it was a common idea among almost everybody that the main character, Master Makan, was partially modeled on the painter Kamal al-Molk; the brigadier Aram was Reza Shah's feared chief of the police, General Ayrom; and the minister, Khayltash, was based on Reza Shah's minister of court, Tay Murtash, who was dismissed, imprisoned, and finally killed" (130). Esfandiari extends the argument into social milieu as she deems Master Makan as an individual who dedicated his life to his Cause. Esfandiari argues that:

Bozorg Alavi's characters are for the most part stereotypes rather than fully realized individuals. The only character that develops and matures in the course of the novel is Farangis. From a frivolous socialite, she is transformed into a politically serious and dedicated woman. She also sees that although Makan is infatuated with her, his political mission takes precedence over his devotion to her. (131).

Esfandiari contends that the novel follows a mediocre strand of narration since the background is not fully complicated. She argues that except for Farangis, who is regarded as a dynamic character, other characters suffer from lack of dynamism and remain static to the very last pages. Esfandiari's evaluation of the novel ends up as follows:

Finally, Alavi gives us the stereotypical tale of a superficial upper-class doll of a woman who grew up in wealth and power but who was rescued from wasting her life (the way the rich supposedly do) by a politically aware middle-class intellectual. Ironically, however, it is Farangis who saves Makan's life by agreeing to marry Aram, even while fully aware that he will never understand what she has done for him. (131-2)

Alavi's depiction of emotional plea in the novel has, however, received radical and antagonistic critiques. While the novel engendered promising reviews by some critics, it was reproved by some of Bozorg Alavi's fellow party members. In her review of the novel regarding its approval, Narguess Farzad stated that:

Although Her Eyes received much praise from the critics, it attracted strong condemnation too. The strongest attack came from some of the author's comrades in the Tudeh Party, and also from critics in the Soviet Union who found Alavi's sympathetic treatment of Farangis, the wealthy and spoiled heroine of the novel, contrary to his professed progressive ideals and social convictions. (398).

The question of ideological devotion in Her Eyes is further explored from another perspective. Throughout the novel, it is not only Master Makan who conveys the impression to wear blinders for his Cause since Agha Raj'ab is detectable as another quintessential instance of ideological devotion. In their study in this regard, Allashti and Lekor- adj depict Agha Raj'ab as "an archetypal example of those people who devote themselves blindfolded to dogmatic and absolute beliefs. He ventures into such beliefs whose lucidity and continuity are gravely questioned" (167). In contrast to Agha Raj'ab stands the character of Master Makan. According to Allashti and Lekoradj, Makan stands for the class of committed intellectuals who "have little faith in people's participation" in social reforms (ibid). Ultimately, this feeble strand of intellectuality dies out due to the repressive state and the rampant mass ignorance.

Furthermore, Hosseyn Payandeh in a seminar (2012) on the novel focuses on the elements of the story including point of view, characterization, and themes. He contends that the novel, having two different narrators, has created a polyphonic atmosphere, which was quite rare at the literary discourse of those days. He states that the novel's approach to the mode of characterization is remarkable in that it has realistically represented the mental condition of both static and dynamic characters.

Siamak Vakili, too, in a paper called "Her Eyes: A Game Between Love and Politics" considers the novel one of the best Persian novels along with Hedayat's The Blind Owl and Golshiri's Prince Ehtejab (1997: 22). He refers to the inevitable and direct impact of Hedayat's fiction on Alevi's whole writing career. Presenting an analogy between the character of the superlunary girl in The Blind Owl and that of Farangis in Her Eyes, he contends that Alavi's characterization of Farangis is not only directly influenced by Hedayat but also moves far beyond Hedayat's perception of beauty.

\section{AN ALTHUSSERIAN READING OF HER EYES}

\section{Predominance of Ideology and Instances of Interpellation}

Although the term 'the subject of ideology' represents itself as neither in Althusser nor in secondary criticism on his oeuvre, the present study approaches the constitution of subjectivity in the novel as an instance that considers the protagonist to be predominantly the subject of ideology. The immanent relationship between the subject and ideology was what Althusser sought to explore in the mature phase of his intellectual career. In Althusser's theory the subject in a modern capitalist state turns into being subjected to the ideological State apparatuses. The conditions in/through which an individual ends in being the subject to the State are reproduced by both the Ideological State Apparatuses and the Repressive State Apparatuses, which are Althusser's terms for the major divisions of the classical Marxist concept of the State apparatus.

In Althusser's theory, individuals are born into ideology and immediately become subject to it. Individuals are called to contribute in the practices of some particular ideologies that are the product of the Ideological State Apparatuses. The subjects presume that they have their own personal thoughts and beliefs and act according to them; however, what really comes into being is that they are "always already subjects."

In Her Eyes, the reader comes across several cases of the process of subjectivization. Master Makan is wholeheartedly devoted to the ideological context in which he was brought 
up in his mature years. Master Makan's manners have been recurrently described in the novel in an explicit way; he is depicted as a character who dedicates his life to the Cause. A clear example is when Farangis sketches out Master Makan's traits: "for him nothing was worth in his personal life. He used to analyze everything, even the cravings from the bottom of his heart, and if they didn't comply with his principles, he would put them aside" (Her Eyes 167). The subjects do not realize their subjection to ideology and consider themselves to be free and independent individuals. On the contrary, ideology is prior to the subjects and makes them feel recognized: "you and I are always already subjects, and as such constantly practice the rituals of ideological recognition, which guarantee for us that we are indeed concrete, individual, distinguishable and (naturally) irreplaceable subjects" (Lenin and Philosophy and other Essays 117).

A major mechanism behind the individual's subjection to ideology is what Althusser called interpellation. Interpellation is the process through which ideology addresses an individual upon its arrival to society and, in this way, makes him the subject to ideology. Ideology, which is a pre-existing structure, interpellates the individual and thus constitutes him as a subject. Interpellation deals with the moment and process of recognition of interaction with ideology.

It is through hailing that ideology ultimately meets its objective: "recruiting subjects from among individuals" (ibid). This process of hailing occurs in such a fashion that the subject assumes himself to be attached to his fellow adherents. In an occasion when Farangis provides a description of Master Makan's cohorts, she explains:

The moments he felt frightened or was in a state of agitation, since his cohorts were arrested and tortured..., he would envision the future of the people whom he was fond of. He would make use of these woes and misfortune for his ideological cause... (Her Eyes 176).

Ideology thus functions to constitute individuals as subjects and individuals are interpellated primarily through the first examples of ideological state apparatuses they are exposed to including the family, the school, and the church. These are institutions that exist before the entry of the individual into them and it could be mentioned that it is by means of diverse ideological apparatuses that ideology renders the individual the subject. On the other hand, the classical humanistic notion contends that the individual subject was the source of his own ideas and beliefs. This was in sharp dissociation from Althusser's foremost thesis on ideology. The anti-humanist approach in Althusser led him to conceive society as a system of elements that have complex relationships. The social formation for Althusser is taken to be manifested in a complex whole including several levels and practices, each one of them enjoying a relative autonomy.

The concept of ideology and its exploitation by the State has long been a hot issue for scholars. Ideological tendencies are also prevalent with literary works in general and in Persian literature in particular. The way ideology is capable of turning an individual into a subject and, subsequently, the subject's mental obsession with the Subject, in its
Althusserian sense, is fully represented in the novel. There exist instances which could be regarded as emblems of Master Makan's resistance to the State's repressive measures. The opening pages of the novel are replete with accounts elaborating on Master Makan's invincible traits consequents of his faith in his principles. In a descriptive account, the foreshadowing remarks on fellow on the page as follows:

No Deprivation scared him. He did not cling to any attachments... He did not give in to the threats of the repressive state. Even though he was exiled from Tehran, he always stood his ground. The worst of it was, he passed away in sheer loneliness (6).

For Althusser, the State employs a variety of measure to carry out its aspired procedure of interpellation. In his theory of ideology the Ideological State Apparatuses are juxtaposed with another key term, Repressive State Apparatuses. This dialectic is necessary to interpellate the individuals in that the State apparatuses cannot be entirely repressive or utterly ideological. In the case of Master Makan, he is subjected to his yearning ideology which is in opposition to the State's ideology. Remarkably, Master Makan is subjected to the hostile ideology which is regarded as another corroboration of interpellation. The State would thus take advantage of its repressive measures labeled as Repressive State Apparatuses. In practice, Althusser's indomitable concept of Repressive State Apparatuses is rather represented in some instances from the novel. While the regime's assumed invincible apparatuses are at work to subject the individual to the dominant ideology, it is not applicable to Master Makan's taken ventures altogether. On the other hand, despite's Master Makan's seemingly insurmountable stance, he cannot fully overcome the specter of ideology.

The subjects are not aware of their subjection to the ideologies. They conjecture that the way they perceive world and its phenomena is totally natural. They are under the influence of ideologies without their knowing the fact. In practice individuals are born into ideologies. Farangis, who has a crush on Master Makan, pays a day's visit to his private studio where she discovers most of the images close to her bearings. The scene is recited as below:

What I discerned in his atelier was that all that depicted in his artifacts came upon me like the bits of my troubled soul. Whatever he had depicted in his paintings seemed to have been articulated from my heart. There was a reciprocal grip and interaction between me and these illustrations. I surmised we had a lot in common, a sense of intimacy and affinity. (191)

The act of 'hailing' turns out well the moment the subject recognizes that the hail is addressed to him/her. In this instance, Farangis is hailed by the same ideology which has already hailed Master Makan in the best possible way. Farangis is deeply influenced by Master Makan's paintings and their significance. She responds to the paintings' thrust since she has recognized that 'the hail' was really addressed to her.

Ideology has always had a captivating charm for the subjects to the extent that many individuals lost their lives because of and for the sake of ideology. Both the protagonist of the story, Master Makan, and, even, Farangis, are situated in 
a complex set of practices that constructs the material conditions of their lives. Louis Althusser believed individuals considered ideology necessary and he postulated his wellknown formula that "no ideology except by the subject and for subjects" (Lenin and Philosophy 170). Althusser rebukes any humanistic approach towards individuals whose actions could be explained in terms of personal beliefs, intents, and inclinations. The subject's full subjection to the Subject is conspicuously observed in the course of the novel. For master Makan, this process is regarded as one that needs total devotion. Having disregarded all of his carnal and mental cravings, for him the significance of life lays in paying your devotion to your Cause appropriately. He lost his love for the sake of the ideals called for by ideology.

\section{The Subject/Subject Model in Her Eyes}

In the Althusserian conception of ideological construction of identity, the subject would never mature into being the Subject. The non-identity between the subject and the Subject shall bring to the subject an ongoing subjection and incomplete identity. The state of non-identity in the classical subject-object relationship is manifested here. The subject is permanently positioned in a condition of either identity or non-identity with the object, Nature, God, substance, or the Subject of ideology.

An Althusserian treatment of the novel illustrates that the impossibility of being a fully devoted subject in Master Makan originally goes back to the impossible full identity of the subject and the Subject. Therefore, a full identity between Master Makan as the subject of ideology and what the Tudeh Party wants him to be, that is the Subject, could not eventuate because of the ongoing non-identity at work.The Subject is here conceived of as the model ideology demands its subjects to follow. The subjects are never heightened by altering into the Subject in that if it occurs, they are no more subjects to the Subject and, in turn, they themselves become the Subject. Ideology always presents a subject model to its subjects and this model is never completely touched by the subject.

The process of subjection to the Subject manifests itself through a different mien. In occasions, the subject presumes a messianic mission for himself to salvage other individuals by means of ideology. Put it in other words, Master Makan is the effect of the ideology he is born into and exposed to. Simultaneously, he is hailed by ideology and is deprived of his autonomy. Althusser later presented an expanded version of his earlier thesis. According to this developed thesis:

Ideology has always already interpellated individuals as subjects, which amounts to making it clear that individuals are always-already interpellated by ideology as subjects, which necessarily lead us to one last proposition: individuals are always-already subjects. (Lenin and Philosophy119)

In the same fashion, Farangis draws the same conclusion when she recognizes she has no chance of winning Master Makan's love. After several encounters with Master Makan, the dismal Farangis whispers to herself, "Hasn't he [Master Makan] proven that he is most attached to his ideal and aspiration (Her Eyes, 177). Evidently, Master Makan has already been fully interpellated by ideological doctrines of the Tudeh Party; he is the subject of ideology and mentally entangled by his ideological aspiration.

In practice, Master Makan is never conscious of his being subjected. He falsely assumes himself to be self-conscious and coherent. Master Makan, the same as any other humanist individuals, considers himself to be decision-maker, self-autonomous, and free. Ideology has already interpellated him as a subject as a consequence of which he thinks of himself as a free agent; however, he also regards himself as one who should proceed to further stages in his commitment to ideology. Following Althusser's designation of the subject, one could argue that Master Makan considers himself as "a subject being, one who submits to a higher authority, and is therefore stripped of all freedom except that of freely accepting his submission" (Lenin and Philosophy 182).This occurs to Master Makan several times while he believes that all of his decision-makings are freely made:

If my country fellowmen could figure out how valiant he was, that he was always deeply apprehensive of the destiny of his people, they would take some decisive steps and get less despondent. (Her Eyes 42)

According to the Tudeh Party's communistic tendencies to establish a purely socialist society, Master Makan identifies himself with his seminal Cause and attributes that Cause to every single individual. In fact, Master Makan not only becomes the subject to the Subject, he also seeks to play a major role in the process of recruiting individual for the Subject. To Farangis's amazement, this subjection has occupied all aspects of his life; she is quite dismal in obtaining a full reciprocation of his love for her:

How do I know if he loves me? It is proved for more than a thousand times that he is attached to his ambition and aspiration. He is not bound to anything but his ideological end. How come that he loves if I don't venture into his risky affairs? (176)

Alavi has skillfully depicted two conflicted characters in parallel lines. Her Eyes demonstrates a full characterization of both Master Makan and Farangis. The ultimate point of the subjection process finds its perceptible way: both of them go on their own way. Master Makan remains a truthful and committed activist whereas Farangis lives the life of a woman of comfortable means. However, Farangis suffers from an internal conflict; the contradictory aspects of her character are represented in the novel in a skilled way. She has been brought up in a well-to-do family. While her father is a regarded as a man easily submitted to the ruling power, her mother has a traditional way of life deeply engaged in superstitious beliefs. Farangis, however, suffers from a shattered personality in that she does not have a stable subjective status. She does not know and cannot choose which way to take: to remain faithful to Master Makan and the ideals of communism, or to continue and enjoy her familial life style, which is state-directed, bourgeois, and well-to-do.

Master Makan, too, as the protagonist of the story, fails in arriving at the state of becoming a Subject. What is notable is that the more Master Makan attempts to cope with the 
model, the more he is required by ideology to follow it. This is an endless chain of subjectivization. This mechanism acts exactly the way superego functions in its Žižekian terms: it is like a bank to which we can never pay off our debts (2005: 145). Based on this theory, the more committed to ideology one remains, the more subjected and alienated he will become. Consequently, Master Makan is permanently subjected by the Subject and never enjoys the state of happiness and freedom from ideological bindings. The transition of the subject into the Subject could be further analysed through exploring the lacks that exist both in the subject and between the subject and the Subject. Throughout the novel there is always a lack between Master Makan and what he is required to act by ideology.

\section{CONCLUSION}

Bozorg Alavi's Her Eyes represents those moments in which the protagonist, Master Makan, is profoundly influenced and haunted by the Tudeh Party's aspirations. The process of ideological subjection is not limited to Master Makan; other characters with whom he interacts are also rendered subjects in the same way. Throughout the novel, there are instances which point to the fact that Master Makan is hailed by the Tudeh Party's ideology and he devoutedly responds to this hailing and ends in being interpellated. In the same fashion, Farangis is destined to be recruited by Master Makan's ideology; as far as Farangis is enchanted with him, his aspired ideologies appear to her as natural. This could be justified through Althusser's postulation of anti-Humanist Marxist formulation. Practically, Farangis's belief that she is free and self-conscious in delineating her worldview is demonstrated to be an illusion in Althusserian terms. This is explicable in terms of her infatuation with Master Makan as well as the working of their aspired ideology. Master Makan and Farangis's illusive image of themselves as being free as well the attempts they make to liberate the society are, ironically, among the functions of ideology even if an opposed one.

Social formation is a complex set of relations between mutually interacting practices, which are not determined by the individual; rather, these practices and their relationships determine the lives of individuals within them. Therefore, the concept of the free and independent subject, as an ideological concept, finds its vein in the novel in a way that there exists no free and self-autonomous subject in society.

The novel provides one of the best literary materials to be read in terms of the often neglected subject-Subject model of the Althusserian framework of thought. The subject is always doomed to fail in achieving the state of full identity with the Subject. The emerging lack in any non-identity condition leads the subject to remain a faithful agent to the Subject. Master Makan is the typical example of those leftist activists who dedicated their life to the Cause, still criticized by ideology and its subjects for being mediocre and not totally a faithful subject.

\section{REFERENCES}

Abedini, Hassan (2013). The History of Persian Fiction. Tehran: Sokhan.

Alavi, Bozorg (2014). Her Eyes (Čašmhāyaš). Fifth Edition. Tehran: Negah.

Althusser, Louis (1969). For Marx. (Trans. Ben Brewster). London: Verso.

Althusser, Louis (1971).Lenin and Philosophy and Other Essays. (Ben Brewster, Trans.), New York: Monthly Review Press.

Althusser, Louis (1976). Essays in Self-Criticism. (Trans. Grahame Lock), London: New Left Books.

Baghinezhad, Abbas and Naser Alizadeh (2015). A Survey in Contemporary Literature II: History, Analysis, and Criticism of Persian Contemporary Prose Genres from Constitutionalism to Today. Tehran: Parseh.

Clarke, Simon et al, eds (1980). "Althusserian Marxism" in One-Dimensional Marxism: Althusser and the Politics of Culture. Simon Clarke. London: Allison and Busby.

Esfandiari, Haleh. (1990). "Her Eyes by Bozorg Alavi; John O'Kane" Rev. Iranian Studies, Vol. XXIII, No. 1 pp. 130-132.

Farzad, Narguess. "Her Eyes by Bozorg Alavi; John O'Kane" Rev. Bibliotheca Persica, Modern Persian Literature Series, No. 9, pp. 398.

HassanpourAllashti, Hossein and Sohrab Mansour Lekoradj."Social-Political Themes in Čašmhāyaš."Journal of Executive Management, Vol. VIII, No. 2, pp 157-170.

Laclau, Ernesto and Lilian Zac (1994). "Minding the Gap: The Subject of Politics," in The Making of Political Identities. Ernesto Laclau, ed. London: Verso, pp. 11-40.

Payandeh, Hossein (2012). "Critical Reading of Alavi's Her Eyes." Seminar in tehran: Arasbaran Hall. Retrieved form, http://www.isna.ir/news/910615/[accessed on 12 July 2017].

Sadeqi, Ismaeil and Mahmoud Aghakhani Bizhani (2011). "The Analysis of a Temporal Structure in Alavi's Her Eyes.” Narrative Studies, Vol. I, No. 2, pp. 48 - 66.

Sepanlou, Mohamadali (1990). Leading Persian Writers. Tehran, Negah.

Sprinker, Michael (1995). "The Legacies of Althusser" in Yale French Studies, No. 88, Depositions: Althusser, Balibar, Macherey, and the Labor of Reading, pp. 201-225.

Vakili, Siamak (1997). “Her Eyes: A Game Between Love and Politics." Aftab Literary Journal, Vol. IV. No. 4, pp. 22-7.

Williams, Caroline (2002). "Althusser and the Persistence of the Subject." Borderlands, Vol. IV, No. 2. Available from: http://www.borderlands.net.au/vol4no2_2005/ williams_interview.htm. [Accessed 14 January 2009].

Žižek, Slavoj (2005). The Metastases of Enjoyment: On Women and Causality. London: Verso. http://www.ibna. $\mathrm{ir} / \mathrm{fa} / \mathrm{doc} / \mathrm{book} / 239029 /[$ accessed on 10 July 2017]. 